\title{
The effect of a mixture of anise and rosemary on broiler performance
}

\author{
Ghalib Alwan Mohammed Al-Kassie, Raghad A.Abd-Al-Jaleel, Akhil M. Mohseen
}

Dept. of Veterinary Public Health, Veterinary Medicine College, Baghdad University, Iraq .

\begin{abstract}
This study was conducted to explore the usage a mixture of anise and rosemary (MAR) as a natural growth promoting in broiler nutrition . Different levels of MAR were added to a standard diet, to determine its effect on body weight gain and feed conversion ratio in comparison with a control group. Three hundred day-old chicks (Ross-308) were randomly assigned in to(5) equal groups of (60) birds each with the (3) replicates . A control group with no added MAR , $0.5 \%$ MAR , $0.75 \%$ MAR , $1 \%$ MAR and $1.25 \%$ MAR were added to the groups 2,3,4 and 5 respectively . Results showed that body weight gain is highly significant $(p \leq 0.05)$ for the groups 2,3 and 4 as compared with control group, similarly feed conversion ratio was improved in the same groups as compared with control group. These results shows that MAR could be considered as a potential natural growth promoter for poultry
\end{abstract}

Keywords : Anise, Rosemary , Performance , Broiler

\section{INTRODUCTION}

Aromatic plants is one of the ban herbal plants played an important role in maintaining human health and becoming more important due to their antimicrobial, stimulating effects on birds digestive system through increasing their digestive enzymes and improve utilization of digestive products through enhancing liver function (Langhout,2000; Williams and Losa,2001; Hernandez et.al .,2004) . Aromatic plants have been used traditionally in the therapy of some diseases for along time in the world.(Singh et.al. ,2002; Valero and Salmeron,2003;Osman et.al.,2005). As an aromatic plant, anise (Pimpinella anisum L.) has been used in medications for a long time as a stimulating effect on digestion and as antiparasitic,(Çabuk et.al,2003), antibacterial (Singh et.al.,2002; Tabanca et.al.,2003), antifungal,(Soliman and Badea,2002) and antipyretic(Afifi et.al.,1994).

Similarly, Rosemary(Rosemarinus afficinalis) is one of the medicinal plants that used in the popularity prescription(Leung,1980),it contains phenotic acids; phenolic diterpenoid bitter substances ; titerpenoid acids; flavonoids; 1.2 to $2.5 \%$ volatile oil and tannins (Leung and Foster,1996 ; Newall,1996) .

Rosemarinus Officinalis is one of only two species in the genus Rosemarinus. It belong to the kingdom plantae, family Lamiales. Rosemary extracts has been shown to improve the shelf life and heat stability of Omega 3 -rich oils, which are prone to going rancid.
The most important constituents of rosemary are carnosal, carnosic acid ,caffeic acid and its derivatives such as rosmarinic acid. These compounds have powerful antioxidant activity. Rosmarinic acid is well absorbed from gastrointestinal tract and from the skin. Rosemary and its constituents have a therapeutic potential in bronchial asthma, peptic ulcer, prostate disorders, inflammatory diseases, liver toxicity, atherosclerosis, stroke, ischemic heart disease, cataract and leukemia . Rosemary is commonly used as a spice and a flavoring agent in food processing.

\section{MATERIALS AND METHODS}

An experiment was carried out at the poultry farm of Veterinary College, Baghdad University. The experiment lasted for 42 days from 3-1-2010 to $14-2-2010$. Two hundred fifty day old chicks (Rose 308) were divided randomly into 5 treatments groups of (50) bird each with 3 replicate. The treatments were allocated to receive the following diets: Group (1) diet were fed normal basal diet free from any herbal plant additions kept as control .Groups (2, 3, 4 and 5)diets were fed as in (1) with addition of ( $0.50,0.75,1$ and $1.25 \%)$ mixture of anise and rosemary on a basal feed of $(500,750,1000,1250$ )gm/100 kg respectively.

Chicks were reared in $(1.5 \mathrm{~m} \times 1.5 \mathrm{~m})$ floor pens with a thick wooden shaving litter system of $(7 \mathrm{~cm})$. Feeding program were induced a couple of diets 
(Starter and finisher) which lasted long for 2 periods $(21,42)$ days respectively .

Diets of each period included the same ingredients and composition for all diets throughout the experiments, diets were formulated to meet or exceed chicks requirements according to National Research Council (NRC, 1994) for that chicks ages. Feed and water was provided ad-libitum during the experiment. The composition of the experimental basal diets is given in table (1).

Table (1): The composition of the experimental basal diets.

\begin{tabular}{|c|c|c|}
\hline Ingredient (\%) & Starter 1-21 day & Finisher22-42 day \\
\hline Yellow Corn & 51 & 53.3 \\
\hline meal (45\% protein ) & 30 & 25 \\
\hline Wheat & 13.8 & 15 \\
\hline Oil & 1 & 2.5 \\
\hline Premix & 2.5 & 2.5 \\
\hline Salt & 0.3 & 0.3 \\
\hline Methionine & 0.1 & 0.1 \\
\hline Lysine & 0.1 & 0.1 \\
\hline Di- Calcium phosphate & 1.2 & 1.2 \\
\hline Calculated chemical analysis & & 3086 \\
\hline ME (Kcal/kg) & 3000 & 19.5 \\
\hline Crude protein \% & 21.3 & 0.52 \\
\hline Calcium \% & 0.69 & 0.69 \\
\hline Avialable Phosphore & 0.74 & 0.31 \\
\hline Methionine & 0.33 & 1.08 \\
\hline Lysine & 1.19 & \\
\hline
\end{tabular}

* Premix :- ( 2.5\%) Provided the following (per Kg of complete diets ) Vit.A 367500 IU , 133500IU Vit.D3, $1920 \mathrm{mg}$ Vit .E , 83.42 Vit. K3 , 50 mg Vit.B1, $150 \mathrm{mg}$ Vit .B2, 500mg Vit.B3 , 177,5 mg Vit. B6 , $0.8 \mathrm{mg}$ Vit.B12 , $600 \mathrm{mg}$ Vit. PP , $24.5 \mathrm{mg}$ folic acid , $27 \mathrm{mg}$ Biotin, $5767.5 \mathrm{mg}$ choline, $2667 \mathrm{mg} \mathrm{Fe}, 333.75 \mathrm{mg} \mathrm{Cu}, 3334.06 \mathrm{mg} \mathrm{Mn}, 203 \mathrm{mg}$ Co $2334.38 \mathrm{mg} \mathrm{Zn,} 100.75 \mathrm{mg} \mathrm{Ca}, 10 \mathrm{mg} \mathrm{Se}$, $65446.46 \mathrm{mg} \mathrm{Ph}, 36667.5 \mathrm{mg}$ DL-Methionine , $200.02 \mathrm{mg}$ Ethoxyquin , $50 \mathrm{mg}$ Flavophospholipol , 30g Fish meal , $1800 \mathrm{~g}$ wheat bran.

Chicks were vaccinated against Newcastle Disease (ND) and Infectious Bronchitis (IB). Body weight was determined throughout the experimental diets periods. Feed intake was recorded for the corresponding periods. At the end of the experiment, three chicks out of each replicate were randomly selected and weighted to obtain live body weight. Birds were slaughtered using knife for complete bleeding, and feathers were plucked. Head, viscera and shanks were removed. Carcass was left for an hour to remove excess water and allowed for over night in a refrigerator at $4 \pm 2^{\circ} \mathrm{C}$ then weighed. Dressing percentage was calculated free from edible giblets (Heart, Gizzard, liver) that weighted separately an calculated as percentage of the carcass weight. Blood samples were taken from the brachial vein by using syringe. These samples were used for the determination of various haematological parameters including (PCV,WBC and RBC counts, hemoglobin $(\mathrm{Hb})$ concentrations and heterophils /lymphocytes ratio) glucose \& cholesterol concentration. Data were analyzed using the General Linear Model procedure of SAS (1996). Duncan's multiple range test was used to detect the differences $(P<0.05)$ among different group means.

\section{RESULT AND DISCUSSION}

Table 2 reveals the effect of different levels of a mixture of anise and rosemary (MAR) on some of the productive performance during different stage of weeks. At the end of the experiment which carried 6 weeks, body weight gain significantly differed ( $p \leq$ 0.05 ) between groups. The highest value was recorded in group 4 (MAR) $1 \%$, followed by (MAR) $0.75 \%$. The above table demonstrates the effect of (MAR) on the feed conversion for the period of weeks. They were significantly differed ( $p \leq 0.05$ ) between groups. Addition of (MAR) at the levels $1 \%$ and $0.75 \%$ respectively to the diets improved feed conversion ratio as compared with others and control group .This improvement was persistent with (MAR) $1 \%$ and $0.75 \%$ groups.

When levels was increased to $1.25 \%$,there is no significant increase $(p \leq 0.05)$ appeared similar to that happened with levels $(0.75 \%)$ respectively, this means that it's impossible to increase levels over known extent, since there is some herbs that may cause toxicity when they are administrated in a large quantities. 
The improvement of body weight gain and conversion ratio for broiler that fed (MAR) may be due to active ingredient such as anethole in anise and borneol, carnosol , carnosic acid and caffeic in rosemary. That was achieved through stimulating effect on digestive system and increases production of digestive products enzymes and improve utilization of digestive products through enhanced liver function (Langhout,2000;Williams and Losa 2011; Cabuk et.al.2003; losa,2001; Hernandez et.al.,2004).

Besides to the active ingredients which have been used in medicating of some diseases (Osman et.al.,2005) stimulating effects on digestion and previously mentioned antibacterial antipyretic action, (Cabuk et.al,2003; Singh et.al.,2002; Tabanca et.al.,2003; Soliman and Badea,2002; Afifi et.al.,1994). This study agreed with other researchers Al-kassie(2008); Osman(2005); Ather(2000) . But unfortunately ,many reports about the value of anise and rosemary in poultry nutrition are very limited and many of research still under study about the ideal percentage that is used single of it.

Table(2): Effect of different levels of a mixture of anis and rosemary on some of the performance \pm standard error on broiler.

\begin{tabular}{|c|c|c|c|c|c|c|c|c|}
\hline & \multicolumn{4}{|c|}{ Body weight gain(gm) } & \multicolumn{4}{|c|}{$\begin{array}{c}\text { Feed conversion ratio(gm feed intake/ } \\
\text { gm.weight gain }\end{array}$} \\
\hline & $0-2$ week & 2-4 week & 4-6 week & $0-6$ week & $0-2$ week & 2-4 week & 4-6 week & $0-6$ week \\
\hline T1 control & $360 \pm 3.8^{b}$ & $770 \pm 12.8^{c}$ & $1322 \pm 33.7^{\mathrm{C}}$ & $2421 \pm 39.7^{c}$ & $1.65 \pm 0.12^{\mathrm{a}}$ & $1.71 \pm 0.39^{\mathrm{a}}$ & $1.84 \pm 0.31^{\mathrm{a}}$ & $1.73 \pm 0.16^{\mathrm{a}}$ \\
\hline $\begin{array}{c}\mathrm{T} 20.5 \% \text { mix of } \\
\text { anise and } \\
\text { rosemary }\end{array}$ & $413 \pm 4.9^{a}$ & $914 \pm 13.7^{b}$ & $1455 \pm 24.6^{a}$ & $2735 \pm 40.6^{a}$ & $1.53 \pm 0.21^{b}$ & $1.61 \pm 0.22^{b}$ & $1.77 \pm 0.41^{b c}$ & $1.64 \pm 0.26^{c}$ \\
\hline $\begin{array}{c}\mathrm{T} 30.75 \% \text { mix } \\
\text { of anise and } \\
\text { rosemary }\end{array}$ & $416 \pm 6.4^{\mathrm{a}}$ & $955 \pm 11.2^{\mathrm{a}}$ & $1461 \pm 31.2^{\mathrm{a}}$ & $2780 \pm 41.3^{\mathrm{a}}$ & $1.56 \pm 0.92^{b}$ & $1.62 \pm 0.29^{b}$ & $1.78 \pm 0.47^{b c}$ & $1.65 \pm 0.29^{b c}$ \\
\hline $\begin{array}{l}\mathrm{T} 41 \% \text { mix of } \\
\text { anise and } \\
\text { rosemary }\end{array}$ & $421 \pm 6.7^{\mathrm{a}}$ & $978 \pm 14.6^{\mathrm{a}}$ & $1473 \pm 35.7^{\mathrm{a}}$ & $2806 \pm 44.3^{a}$ & $1.59 \pm 0.31^{a}$ & $1.67 \pm 0.21^{a}$ & $1.79 \pm 0.29^{b}$ & $1.68 \pm 0.22^{b}$ \\
\hline $\begin{array}{c}\text { T5 } 1.25 \% \text { mix } \\
\text { of anise and } \\
\text { rosemary }\end{array}$ & $370 \pm 4.6^{\mathrm{b}}$ & $885 \pm 14.3^{\mathrm{bc}}$ & $1391 \pm 29.7^{b}$ & $2604 \pm 41.2^{b}$ & $1.61 \pm 0.19^{a}$ & $1.68 \pm 0.38^{\mathrm{a}}$ & $1.81 \pm 0.38^{\mathrm{ab}}$ & $1.70 \pm 0.21^{\mathrm{a}}$ \\
\hline
\end{tabular}

Means with different superscripts in the same raw differ significantly $(p \leq 0.05)$

\section{REFERENCES}

Afifi,N.A; E.A. Ramadan ; El-Kashoury and H.A. El-Banna. 1994. Some pharmacological activities of essential oils of certain umbeliferous fruits. Vet.Med. J.Giza, 42:8592.

Al-Kassie,G.A.M. 2008. The effect of Anise and Rosemary on broiler performance. Int.Poult. Sci. , 7(3):243245,2008 .

Ather,M.A.M. 2000. Polyherbal additive proves effective against vertical transmission of IBD .Wrld PoultryElsevier, 16:50-52 .

Cabuk,M. ; A.Alcicek ; M.Bozkurt and N.Imre. 2003. Antimicrobial properties of the essential oils isolated from aromatic plants and using possibility as alternative feed additives. 11.National Animal Nutrition Congress, 18-20 September, pp:184-187.

Hernandez,F. ;J.Madrid ; V.Garcia ; J.Orengo and M.D.Megias.2004. Influence of two plant extract on broiler performance, digestibility and digestive organ size. Poult.Sci. ,83:169-174.
Langhout,P. 2000. New additives for broiler chickens. World Poultry-Elservier , 16:22-25.

Leung,A. 1980. Encyclopedia of Common Natural Ingredients Used in Food, Drugs and Cosmetics. NY:Wiley.

Leung,A.Y. and S.Foster. 1996. Encyclopedia of Common Natural Ingredients Used in Food, Drugs and Cosmetics , $2^{\text {nd }}$ Ed. New York:John Wiley sons, Inc.

Newall,C. 1996. Herbal Medicines : A Guide for Health Care Professionals.London:Pharmaceutical press.

National Research Council (NRC), 1994. Nutrient Requirements of Poultry 9th Edn. National Academy Press, Washington, DC. of Alletchs 10th Annual Symposium. Nottingham University Press, Nottingham, UK

Osman,N.E. ; G.Talat ; C.Mehmet; D.Bestami and U.G.Simsek.2005. The Effect of an Essential Oil Mix Derived from Oregano, Clove and Anise on Broiler performance . Int.Poult.Sci.4(11):879-884. 
Agric. Biol. J. N. Am., 2011, 2(9): 1279-1282

SAS.2001. SAS/STAT Users Guide for Personal Computer.Release 6.18 SAS Institute, Inc. , Cary,N.C. ,USA.

Singh,G. ; I.P.Kapoor ; S.K.Pandey ; U.K.Singh and R.K.Singh.2002.Studies on essential oils:part 10 ; antibacterial activity of volatile oils of some spices. Phytother Res. ,16:680-682.

Soliman,K.M. and R.I.Badea. 2002. Effect of oil extracted from some medicinal plants on different mycotoxigenic fungi. Food Chemistry and Toxicology,40:1669-1675.
Tabanca,N. ; E.Bedir ; N.Kirimer ; K.H.Baser ; S.I.Khan; M.R. Jacob and I.A. Khan. 2003. Antimicrobial compounds from Pimpinella species growing in Turkey . Planta Med. ,69:933-938.

Valero, M. and M.C. Salmeron, 2003. Antimicrobial activity of 11 essential oil against Bacillus cereus in tyndallized carrot broth. Int. J. Food Microbial, 85:73-81.

Williams, P. and R.Losa .2001. The use of essential oils and their compounds in poultry nutrition. World Poultry - Elsevier, 17:14-15. 